\title{
EFEKTIVITAS ART THERAPY DALAM MENURUNKAN KECEMASAN PADA IBU YANG MEMILIKI ANAK PENDERITA KANKER
}

\author{
Christella Ruslan ${ }^{1}$, Monty P. Satiadarma ${ }^{2}$, Untung Subroto ${ }^{3}$ \\ ${ }^{1}$ Jurusan Psikologi Profesi, Universitas Tarumanagara Jakarta \\ Email: christella.717181003@stu.untar.ac.id \\ ${ }^{2}$ Fakultas Psikologi, Universitas Tarumanagara Jakarta \\ Email: montys@fpsi.untar.ac.id \\ ${ }^{3}$ Fakultas Psikologi, Universitas Tarumanagara Jakarta \\ Email: untungs@fpsi.untar.ac.id
}

Masuk: 20-11-2020, revisi: 25-03-2021, diterima untuk diterbitkan: 26-03-2021

\begin{abstract}
Cancer is caused by the uncontrolled development of cells in the body and can cause death in someone who experiences it. This condition can affect the physical and psychological health of parents, especially mothers who look after and care for their children. Seeing this, having a child with cancer can certainly cause anxiety in a mother. At the same time, a mother is certainly required to provide emotional support to her child who is sick. This study aims to examine the effectiveness of art therapy in reducing anxiety in mothers of children with cancer. Art therapy that is applied to mothers who have children with cancer can help reduce the anxiety they feel because through this therapy participants are assisted in exploring, releasing their emotions and feelings of anxiety. Through this intervention, mothers who have children with cancer can experience catharsis and express their feelings. Participants in this study consisted of two mothers who have children with cancer. The design of this study is a quasi-experimental study by testing the pretest and posttest using the State-Trait Anxiety Inventory (STAI) measurement tool in measuring state and trait anxiety from mothers who have children with cancer. The results of the study found that there was a decrease in the number of state anxiety by 14 in the R participant and 8 in the RS participant. Based on this, it can be concluded that art therapy intervention can reduce the state anxiety in mothers who have children with cancer.
\end{abstract}

Keywords: Anxiety, art therapy, mothers, children, cancer

\begin{abstract}
ABSTRAK
Kanker disebabkan oleh adanya perkembangan sel yang tidak terkendali dalam tubuh dan dapat menyebabkan kematian pada seseorang yang mengalaminya. Kondisi ini dapat memengaruhi kesehatan secara fisik dan psikologis dari orang tua, terutama ibu yang menjaga serta merawat anaknya. Melihat hal ini, memiliki anak penderita kanker tentu dapat menimbulkan kecemasan dalam diri seorang ibu. Pada saat yang bersamaan, seorang ibu tentu dituntut untuk memberi dukungan secara emosional kepada anaknya yang sedang sakit. Penelitian ini bertujuan untuk meneliti efektivitas dari art therapy dalam menurunkan kecemasan pada ibu yang memiliki anak penderita kanker. Art therapy yang diterapkan pada ibu yang memiliki anak penderita kanker dapat membantu menurunkan kecemasan yang dirasakan karena melalui terapi ini partisipan dibantu agar bisa mengeksplorasi dan mengeluarkan emosi serta perasaan cemas yang dimiliki. Melalui intervensi art therapy ini, ibu yang memiliki anak penderita kanker dapat melakukan katarsis dan mengungkapkan perasaannya. Partisipan dalam penelitian ini terdiri atas dua orang ibu yang memiliki anak penderita kanker. Adapun desain penelitian ini adalah kuasi-eksperimental dengan menguji pretest dan posttest yang menggunakan alat ukur State-Trait Anxiety Inventory (STAI) dalam mengukur kecemasan secara state dan trait dari ibu yang memiliki anak penderita kanker. Hasil penelitian menemukan adanya penurunan angka dari skor state anxiety sebesar 14 pada partisipan R dan 8 pada partisipan RS. Berdasarkan hal tersebut, dapat disimpulkan bahwa intervensi art therapy dapat membantu menurunkan kecemasan secara state anxiety pada ibu yang memiliki anak penderita kanker.
\end{abstract}

Kata Kunci: Kecemasan, terapi seni, ibu, anak, kanker

\section{PENDAHULUAN}

\section{Latar Belakang}

Kanker didefinisikan sebagai suatu penyakit yang menyebabkan sel-sel yang terdapat di dalam tubuh melakukan pembelahan secara tidak terkontrol dan abnormal serta dapat menular ke berbagai jaringan tubuh lainnya (National Cancer Institute, 2015). Penyakit kanker tidak hanya 
dialami oleh orang dewasa, tetapi juga dapat dialami oleh anak-anak (Sulistiowati et al., 2016). Kementerian Kesehatan Republik Indonesia (2015) juga mendukung pernyataan tersebut dengan mengatakan bahwa prevalensi penyakit kanker tertinggi adalah kelompok usia 75 tahun ke atas, tetapi terdapat juga kasus pada anak-anak. Menurut Kementerian Kesehatan Republik Indonesia (2016), berdasarkan hasil Riset Kesehatan Dasar tahun 2013, tercatat bahwa prevalensi kasus penyakit kanker pada anak adalah sebanyak 16.291 kasus. Terdapat catatan yang menunjukkan bahwa kanker merupakan penyebab kematian kedua terbesar pada anak-anak yang masih berusia antara 5-14 tahun setelah penyebab pertama, yaitu cedera dan kecelakaan (Kementerian Kesehatan Republik Indonesia, 2015).

Kasus kanker yang umumnya terjadi pada anak-anak adalah leukemia kemudian diikuti dengan limfoma serta tumor pada sistem saraf pusat (Safitri et al., 2017). Hal yang dapat disebabkan ketika seseorang mengalami penyakit kanker adalah kematian (Kazak \& Noll, 2015). Hal ini tentu tidak hanya berdampak pada anaknya saja, tetapi dapat memengaruhi aspek kehidupan dalam keluarga yang mengalami kejadian ini (Wati \& Qoyyimah, 2018). Rashi et al. (2018) juga menyebutkan bahwa diagnosis kanker memberikan dampak pada orang tua dan dapat menyebabkan perubahan besar dalam realita kehidupan yang dapat memengaruhi aspek psikologis.

Saat orang tua mengetahui anaknya diberikan diagnosis terkena kanker, itu merupakan suatu pukulan yang berat dan pada umumnya orang tua akan merasa kaget, tidak percaya, sedih, merasa bersalah, marah, dan cemas (Rani et al., 2015). Rahmani et al. (2018) menyebutkan tingkat kecemasan meningkat pada orang tua yang mengetahui anaknya memiliki penyakit kanker dan hal ini dapat memengaruhi kesehatan dari orang tua itu sendiri. Kecemasan merupakan suatu kondisi emosi yang tidak menyenangkan dan dapat dicirikan dengan adanya perasaan ketegangan yang subjektif, perasaan gugup, dan kekhawatiran yang disertai adanya peningkatan atau aktivasi dari sistem saraf autonomic (Spielberger et al., 1983). Tingkat kecemasan dapat menjadi lebih tinggi pada orang tua yang memiliki anak penderita kanker karena hal ini merupakan stressor paling intens yang dapat dirasakan, mengganggu fungsi keluarga, mengalami stres karena kondisi keuangan, harus menghadapi penyakit yang bisa kambuh, serta karena kanker juga merupakan penyakit yang dapat mengancam nyawa (Rahmani, et al., 2018).

Sebuah penelitian mengenai orang tua yang memiliki anak dengan penyakit kanker menunjukkan persentase sebesar $17.1 \%$ untuk ibu dan $8.0 \%$ untuk ayah yang mengalami gejala kecemasan (Thabet \& Mona, 2017). Hal tersebut menunjukkan persentase kecemasan ibu lebih tinggi karena ibu lebih banyak menghabiskan waktu untuk menjaga dan merawat anaknya (Rani et al., 2015). Reaksi-reaksi lain yang dapat ditunjukkan berupa merasa harus bertanggung jawab atas situasi yang ada karena telah melahirkan anak yang tidak sehat, serta merasa tidak bisa melindungi anak mereka dari penyakit yang kronis tersebut. Kemudian, melihat anaknya yang harus memiliki penyakit kanker dapat merasa bahwa segala harapan, mimpi, serta ekspektasi yang awalnya ada menjadi hancur (Theofanidis, 2014). Selain itu, memiliki anak penderita kanker berarti ibu juga harus siap untuk melihat anaknya menghadapi kematian akibat penyakit yang dideritanya (Lou et al., 2015).

Terdapat gejala fisik yang dapat muncul pada seorang ibu yang memiliki anak dengan penyakit kanker yaitu, kelelahan, sakit kepala, kehilangan nafsu makan, serta sulit tidur (Safitri et al., 2017). Elcigil dan Conk (dalam Safitri et al., 2017) juga menyebutkan gejala psikologis pada ibu seperti mudah gelisah, cepat marah, stres, dan sensitif. González-Arratia dan Valdez (2011) menjelaskan sebagai seorang ibu walau berada dalam situasi yang sulit, ia juga memiliki peran penting dalam proses pengobatan yang harus dijalankan oleh anaknya. 
Berdasarkan hal tersebut, kecemasan yang dialami oleh ibu perlu diatasi karena tidak hanya berdampak pada dirinya saja, tetapi dapat memengaruhi kondisi anaknya. Hal ini didukung oleh Norberg dan Boman (2008) yang memaparkan bahwa orang tua merupakan sumber utama dalam memberikan dukungan secara emosional kepada anak mereka yang memiliki penyakit kanker. Dalam penelitian ini, intervensi yang dipilih untuk membantu mengatasi kecemasan yang dialami adalah art therapy.

Menurut American Art Therapy Association (dalam Malchiodi, 2005), art therapy menggunakan media, gambar, dan proses yang kreatif serta respon dari klien untuk menciptakan suatu karya dari hasil refleksi mengenai perkembangan, kemampuan, kepribadian, dan konflik. Hal ini merupakan proses terapeutik untuk mengatasi konflik emosional, meningkatkan kesadaran sendiri, meningkatkan kemampuan sosial, mengatur perilaku yang dimiliki, memecahkan masalah, mengurangi kecemasan, berorientasi pada realitas, serta meningkatkan self-esteem. Ganim (1999) menjelaskan bagaimana seni itu sendiri dapat membantu individu agar dapat mengekspresikan perasaan dan emosi yang dimiliki. Melalui art therapy, klien diajarkan bagaimana cara untuk mengakses imagistic perception dari perasaan dan emosi mereka dari masa lalu maupun masa saat ini dan melepaskannya melalui seni sehingga dapat merasa lebih baik secara fisik dan emosi.

Berbagai penelitian mengenai intervensi art therapy itu sendiri telah banyak dilakukan pada pasien kanker, klien yang sedang mengatasi berbagai kondisi berkaitan dengan medis, kesehatan mental dari klien, klien yang sedang menghadapi trauma, individu dengan lanjut usia, bahkan sampai dengan klien yang sedang menghadapi rintangan dalam kehidupan sehari-hari (Regev \& CohenYatziv, 2018). Hal ini dikarenakan art therapy itu sendiri dapat menjadi cara untuk mengungkapkan emosi yang ada seperti, perasaan cemas, rendah diri, marah, takut ditolak, dan berbagai emosi lainnya (Permatasari et al., 2017). Adriani dan Satiadarma (2011) juga menemukan efektivitas dari intervensi art therapy itu sendiri dalam menurunkan kecemasan. Berangkat dari hal tersebut, terlihat bahwa art therapy dapat diterapkan untuk partisipan dalam penelitian ini. Berdasarkan berbagai penjelasan yang telah dipaparkan di atas, peneliti secara spesifik akan menerapkan art therapy pada ibu yang memiliki anak penderita kanker sebagai sarana untuk menurunkan kecemasan yang dimiliki.

\section{Rumusan Masalah}

Berdasarkan paparan latar belakang yang sudah dijelaskan, maka rumusan masalah dalam penelitian ini adalah apakah art therapy dapat menurunkan kecemasan pada ibu yang memiliki anak penderita kanker?

\section{METODE PENELITIAN}

\section{Partisipan penelitian}

Partisipan penelitian ini adalah seorang ibu yang memiliki anak dengan penyakit kanker, sedang merawat anaknya, anak dengan penyakit kanker telah diberikan diagnosis oleh dokter, dan berusia 20-65 tahun. Adapun penelitian ini terdiri atas dua orang ibu yang memenuhi kriteria penelitian dan bersedia untuk mengikuti penelitian ini, yaitu R yang berusia 39 tahun dan RS yang berusia 41 tahun.

\section{Desain penelitian}

Desain penelitian ini menggunakan kuasi-eksperimental dengan menguji pretest dan posttest yang menggunakan alat ukur State-Trait Anxiety Inventory (STAI) dalam mengukur kecemasan secara state dan trait dari ibu yang memiliki anak penderita kanker. 


\section{Instrumen penelitian}

Dalam penelitian ini, instrumen penelitian yang digunakan adalah State-Trait Anxiety Inventory atau STAI (Spielberger et al., 1983). Alat ukur ini dapat mengukur dua hal, yaitu State Anxiety (SAnxiety) dan Trait Anxiety (S-Anxiety). Masing-masing dari kedua jenis skala tersebut terdiri atas 20 butir pernyataan. Hal yang diukur pada skala $S$-Anxiety adalah mengenai bagaimana perasaan yang dirasakan "pada saat ini", sedangkan T-Anxiety mengukur bagaimana perasaan yang dirasakan "secara umum". Kedua jenis skala ini memiliki masing-masing instruksi yang berbeda dalam pengisiannya. Adapun dikatakan bahwa pengukuran reliabilitas terhadap alat ukur ini dengan menggunakan teknik konsistensi internal telah memperoleh hasil yang baik dari berbagai penelitian yang telah dilakukan. Skor reliabilitas dari S-Anxiety memiliki koefisien median yaitu .93, sedangkan skor reliabilitas pada T-Anxiety memiliki koefisien median sebesar .90 (Spielberger et al., 1983). Kemudian, validitas dari alat ukur ini juga telah diuji secara validitas konstruk. Hasil validitas dari alat ukur STAI ketika dibandingkan dengan alat ukur kecemasan lainnya menghasilkan korelasi antara .85-.73. Balsamo et al., (2013) juga menemukan nilai validitas dari alat ukur STAI yaitu nilai koefisien antara .88 dan .96 .

\section{HASIL DAN PEMBAHASAN}

\section{Tahap Pelaksanaan Intervensi Art Therapy}

Dalam penelitian ini, intervensi art therapy yang digunakan adalah intervensi Ganim (1999). Ganim (1999) menjelaskan bahwa terdapat empat tahap dasar dalam art therapy, yaitu expressing an emotion, healing the mind, healing the body, dan transformation of the spirit. Intervensi yang diterapkan pada partisipan dalam penelitian ini telah dirancang sebanyak delapan sesi pertemuan.

Pada sesi yang pertama, peneliti akan terlebih dahulu memberikan informed consent kepada partisipan sebagai lembar persetujuan untuk mengikuti penelitian ini. Setelah itu, peneliti juga akan memberikan kuesioner STAI kepada partisipan untuk diisi. Selanjutnya, peneliti akan melakukan proses wawancara guna memahami kasus partisipan secara lebih mendalam. Kemudian, pada sesi kedua peneliti akan mengenalkan alat dan bahan yang digunakan dalam intervensi art therapy yang akan dijalankan pada sesi-sesi selanjutnya dengan memberikan kegiatan free drawing kepada partisipan.

Tahap pertama dari rancangan intervensi art therapy dimulai dalam sesi ketiga, yaitu melakukan kegiatan tahap expressing an emotion. Sesi ini bertujuan untuk menyadari perasaan yang dimiliki dengan mengekspresikannya terkait dengan kondisi memiliki anak penderita kanker. Setelah itu, partisipan juga dibantu untuk menyadari motivasi dan keinginan untuk pulih dari perasaan cemas yang dimiliki.

Sesi keempat dari intervensi art therapy ini merupakan tahap yang kedua, yaitu healing the mind. Sesi ini bertujuan untuk menghadapi emosi yang tidak menyenangkan atau menyakitkan terkait dengan kondisi anak yang memiliki penyakit kanker. Kemudian, mencoba menciptakan emosi atau perasaan yang positif sebagai penggantinya. Lalu, pada sesi kelima melanjutkan tahap berikutnya, yaitu healing the body. Sesi kelima memiliki tujuan agar partisipan merasakan kemudian menggambarkan rasa sakit pada suatu bagian tubuh karena kondisi memiliki anak penderita kanker, sehingga menyadari kebutuhan yang diperlukan untuk mengurangi kecemasan dalam dirinya. Pada sesi keenam juga masih pada tahap healing the body, di mana partisipan dapat menyadari dan menggambarkan dirinya sebagai seseorang yang sembuh secara pikiran, tubuh, dan jiwa. 
Sesi yang ketujuh merupakan tahap dasar terakhir, yaitu transformation of the spirit. Dalam sesi ketujuh, tujuan yang ingin dicapai adalah partisipan dapat menelaah kembali dan merefleksikan masalah yang telah dialami serta menyadari apa yang harus dilakukan pada masa yang akan datang. Terakhir, sesi kedelapan, peneliti kembali memberikan kuesioner STAI kepada partisipan dan kemudian melakukan evaluasi serta terminasi kepada partisipan.

\section{Hasil penelitian}

Perbandingan hasil skor state anxiety, partisipan R menunjukkan penurunan skor sebesar 14 yaitu dari 59 menjadi 45. Kemudian, hasil perbandingan skor trait anxiety pada partisipan $\mathrm{R}$ terdapat penurunan skor 2, yaitu dari skor 52 menjadi 50. Pada partisipan RS, terjadi penurunan skor sebesar 8, yaitu dari 63 menjadi 55. Lalu, trait anxiety dari partisipan RS sendiri diperoleh hasil penurunan 3 skor, yaitu dari skor 52 menjadi 49.

\section{Diskusi}

Hasil penelitian menunjukkan bahwa intervensi art therapy dapat membantu menurunkan kecemasan ibu yang memiliki anak penderita kanker secara state anxiety. Tovilovic et al. (2009) menjelaskan bahwa state anxiety didefinisikan sebagai respon emosional seseorang yang tidak menyenangkan dalam menghadapi situasi yang mengancam. Situasi yang mengancam dalam hal ini yang dihadapi oleh seorang ibu adalah memiliki anak yang sedang mengalami penyakit kanker.

Rahmani et al. (2018) menyebutkan bahwa memiliki anak dengan penyakit kanker merupakan stressor paling intens yang dapat dirasakan. Hal ini sejalan dengan ungkapan partisipan yang merasa sebagai seorang ibu, tentu tidak mudah dalam menghadapi situasi ini karena mereka tidak selalu mampu untuk mengungkapkan pikiran serta perasaan yang mereka miliki pada saat menghadapi kondisi anaknya yang sakit. Akan tetapi, pada saat yang bersamaan, mereka juga dituntut untuk menjaga dan merawat anaknya serta harus terus menjadi sosok yang kuat bagi keluarganya. Art therapy membantu ibu dengan anak penderita kanker karena terdapat proses katarsis sehingga mereka dapat melepaskan perasaan yang terasa mengganggu dan bahkan menyakitkan terutama emosi yang sulit untuk diungkapkan melalui media gambar tersebut (Malchiodi, 2005).

Art therapy itu sendiri merupakan media yang aman digunakan karena ketika seseorang dengan tingkat kecemasan tinggi hanya membicarakan pengalaman yang traumatis baginya, hal ini dapat membangkitkan ketakutan dalam diri mereka. Akan tetapi, ketika seseorang membuat suatu karya seni, kegiatan ini membuatnya berjarak dari perasaan cemas yang dirasakannya (Abbing et al., 2019). Van Gerven (dalam Abbing et al., 2019) juga menjelaskan bahwa mekanisme dari proses membuat karya seni itu sendiri dapat menyebabkan seseorang merasa dalam suatu kontrol tertentu sehingga hal ini membantu menyeimbangkan perasaan cemas dalam dirinya.

Dari intervensi art therapy yang diberikan kepada partisipan, ibu yang memiliki anak penderita kanker juga dapat menemukan insight agar mampu mengatasi permasalahan yang dimiliki. Hal tersebut juga dapat membantu diri mereka untuk berdamai dengan kondisi dari permasalahannya, sehingga dapat mengarahkan diri untuk berubah menjadi lebih positif serta dapat mengalami penyembuhan (Adriani \& Satiadarma, 2011).

Adapun hasil skor trait anxiety cenderung tidak berubah banyak jika dilihat dari angkanya. Hal ini dikarenakan art therapy yang diterapkan sebagai intervensi penelitian berfokus dalam mengatasi kecemasan yang dimiliki partisipan terkait kondisi anaknya yang memiliki penyakit kanker. Selain itu, Tovilovic et al. (2009) menjelaskan bahwa trait anxiety merupakan suatu respon emosional 
seseorang yang cenderung lebih konsisten dalam menghadapi situasi. Adapun terdapat juga penelitian dengan art therapy yang menemukan hasil bahwa trait anxiety memang cenderung lebih stabil dan sulit untuk diubah (Visnola et al., 2010).

\section{KESIMPULAN DAN SARAN}

Berdasarkan penelitian yang telah dilakukan, dapat disimpulkan bahwa intervensi dengan menggunakan art therapy dapat membantu menurunkan kecemasan ibu yang memiliki anak dengan penderita kanker. Akan tetapi, jika dilihat hasil skor yang diperoleh dari alat ukur STAI, terlihat ada penurunan pada state anxiety, sedangkan pada trait anxiety secara keseluruhan tidak banyak berubah. Hal ini dikarenakan trait anxiety merupakan hal yang lebih stabil dan sulit untuk diubah (Visnola et al., 2010). Hasil penelitian menemukan adanya penurunan kecemasan secara state anxiety pada ibu. Melalui art therapy, seseorang dapat memahami persepsi serta perasaan dalam diri sehingga membantunya untuk mencari cara dalam menyelesaikan permasalahan yang dihadapi dan pada akhirnya menemukan harapan hidup lebih baik lagi (Adriani \& Satiadarma, 2011).

Dari penelitian ini, hasil yang telah ditemukan dapat menjadi sumber informasi bagi para praktisi kesehatan mental agar dapat mempertimbangkan penggunaan intervensi art therapy dalam mengatasi kecemasan yang dialami, terutama pada ibu yang memiliki anak penderita kanker. Kemudian, pihak rumah sakit juga dapat mempertimbangkan bahwa art therapy sebagai salah satu terapi yang bisa diaplikasikan dalam menangani masalah emosional yang dimiliki ibu dengan anak penderita kanker. Hal yang dapat dilakukan adalah merancang suatu kegiatan bermanfaat seperti art therapy untuk para ibu secara berkelompok. Adanya dukungan dari sesama ibu yang menghadapi situasi serupa dapat memunculkan perasaan bahwa mereka tidak sendiri, sehingga hal ini dapat membantu mengatasi kecemasan yang dialami. Selain itu, art therapy sebenarnya juga dapat diberikan kepada anak yang sedang mengalami penyakit kanker.

Saran untuk penelitian selanjutnya, hal yang dapat dicoba adalah mempertimbangkan untuk meneliti ayah dari anak yang memiliki penyakit kanker sebagai partisipan. Hal tersebut juga dapat memberi pengaruh terhadap fungsi keluarga di mana tidak hanya ibu yang merasa cemas, tetapi ayah juga dapat merasakan kecemasan tersebut.

\section{Ucapan Terima Kasih (Acknowledgement)}

Ucapan terima kasih diberikan kepada pihak rumah sakit yang telah mengenalkan peneliti kepada seorang dokter spesialis onkologi anak sehingga peneliti dapat dikenalkan kepada berbagai ibu yang memiliki anak penderita kanker. Peneliti juga mengucapkan terima kasih kepada partisipan yang telah memberikan waktunya untuk bersedia menjadi partisipan dalam penelitian yang dilaksanakan ini.

\section{REFERENSI}

Abbing, A., Baars, E. W., de Sonneville, L., Ponstein, A. S., \& Swaab, H. (2019). The effectiveness of art therapy for anxiety in adult women: A randomized controlled trial. Frontiers in Psychology, 10(1203). https://doi.org/10.3389/fpsyg.2019.01203

Adriani, S. N., \& Satiadarma, M. P. (2011). Efektivitas art therapy dalam mengurangi kecemasan pada remaja pasien leukimia. Indonesian Journal of Cancer, 5(1), 31-47.

Balsamo, M., Romanelli, R., Innamorati, M., Ciccarese, G., Carlucci, L., \& Saggino, A. (2013). The state-trait anxiety inventory: Shadows and lights on its construct validity. Journal of Psychopathology Behavioral Assessment, 35(1). https://doi.org/10.1007/s10862-013-93545 
Ganim, B. (1999). Art and healing: Using expressive art to heal your body, mind, and spirit. Three Rivers Press.

González-Arratia, N. I., \& Valdez, D. N. Y. J. L. (2011). Resilience in mothers and children with cancer. Psicooncología, 8(1), 113-123. https://doi.org/10.5209/rev_psic.2011.v8.n1.9

Kazak, A, E., \& Noll, R. B. (2015). The integration of psychology in pediatric oncology research and practice: Collaboration to improve care and outcomes for children and families. American Psychologist, 70(2), 146.

Kementerian Kesehatan Republik Indonesia. (2016, February 15). Kendalikan Kanker pada Anak. http://www.depkes.go.id/article/view/16021600001/kendalikan- kanker-pada-anak.html

Kementerian Kesehatan Republik Indonesia (2015). Situasi penyakit kanker: Data dan informasi kesehatan. Buletin Jendela Data dan Informasi.

Lou, H., Mu, P., Wong, T., \& Mao, H. (2015). A retrospective study of mothers' perspectives of the lived experience of anticipatory loss of a child from a terminal brain tumor. Cancer Nursing, 38(4), 298-304. https://doi.org/10.1097/NCC.0000000000000178

Malchiodi, C. A. (2005). Expressive therapies. The Guilford Press.

National Cancer Institute. (2015, February 9). What Is Cancer? https://www.cancer.gov/aboutcancer/understanding/what-is-cancer

Norberg, A. L., \& Boman, K. K. (2008). Parent distress in childhood cancer: A comparative evaluation of posttraumatic stress symptoms, depression and anxiety. Acta Oncologica, 47, 267-274.

Permatasari, A. E., Marat, S., \& Suparman, M. Y. (2017). Penerapan art therapy untuk menurunkan depresi pada lansia di panti werdha X. Jurnal Muara Ilmu Sosial, Humaniora, dan Seni, l(1), 116-126.

Rahmani, A., Azadi, A., Pakpour, V., Faghani, S., \& Afsari, E. A. (2018). Anxiety and depression: A cross-sectional survey among parents of children with cancer. Indian Journal of Palliative Care, 24(1), 82-85. Doi:10.4103/IJPC_141_17

Rani, M. V. I., Dundu, A. E., \& Kaunang, T. M. D. (2015). Gambaran tingkat kecemasan pada ibu yang anaknya menderita leukimia limfoblastik akut di rsup prof. dr. r. d. kandou manado. Journal e-Clinic, 3(1), 440-444.

Regev, D., \& Cohen-Yatziv, L. (2018). Effectiveness of art therapy with adult clients in 2018what progress has been made?. Frontiers in Psychology, 9(1531). https://doi.org/10.3389/fpsyg.2018.01531

Safitri, Y., Rusyidi, B., \& Taftazani, B. M. (2017). Dukungan sosial terhadap orangtua anak penderita kanker di yayasan komunitas taufan jakarta timur. Jurnal Penelitian \& PKM, 4(2), 129-389. ISSN:2442-448x(p),2581-1126(e)

Spielberger, C. D., Gorsuch, R.L., Lushene, R., Vagg, P. R., \& Jacobs, G.A. (1983). State-trait anxiety inventory for adults: Manual, instrument, and scoring guide. Mind Garden.

Sulistiowati, E., Lolong, D. B., \& Pangaribuan, L. (2016). Gambaran penyebab kematian karena kanker di 15 kabupaten/kota, indonesia tahun 2011. Buletin Penelitian Sistem Kesehatan, 19(2), 119-125.

Thabet, A. M., \& Mona, M. (2017). The relationship between ptsd, anxiety and depression in palestinian children with cancer and mental health of mothers. Journal of Psychology and Brain studies, 1(2), 1-9.

Theofanidis, D. (2014). Chronic illness in childhood: Psychosocial adaptation and nursing support for the child and family. Health Science Journal, 1-9.

Tovilovic, S., Novovic, Z., Mihic, L., \& Jovanovic, V. (2009). The role of trait anxiety in induction of state anxiety. Psihologija, 42(2), 491-504. Doi:10.2298/PSI0904491T 
Visnola, D., Sprūdža, D., Bake, M. A., \& Pike, A. (2010). Effects of art therapy on stress and anxiety of employees. Proceedings of the Latvian Academy of Sciences, 64(1/2), 85-91. https://doi.org/10.2478/v10046-010-0020-y

Wati, N. L., \& Qoyyimah, F. (2018). Tingkat stres ibu yang mempunyai anak kanker leukimia di rumah cinta bandung. Jurnal Keperawatan BSI, 6(1), 69-76. 